\title{
Elementary Properties of Axonal Calcium Currents in Type B Photoreceptors in Hermissenda crassicornis
}

\author{
Catherine T. Tamse ${ }^{1}$ and Ebenezer N. Yamoah ${ }^{1,2}$ \\ ${ }^{1}$ Center for Neuroscience, Department of Otolaryngology, University of California, Davis, Davis, California 95616, and \\ 2Marine Biological Laboratory, Woods Hole, Massachusetts 02543
}

Axons of the type B photoreceptors form synapses with hair cells and interneurons that are involved in classical conditioning in Hermissenda. We examined the differences in the $\mathrm{Ca}^{2+}$ channels expressed in the soma and axons of the $B$ photoreceptors by direct functional recordings of single-channel currents. Although the soma of the $\mathrm{B}$ cells express two $\mathrm{Ca}^{2+}$ current subtypes, a transient BayK 8644-insensitive ( $\sim 17 \mathrm{pS})$ current and a sustained BayK 8644-sensitive ( $\sim 10$ pS) current, the axons expressed only the latter. The axonal $\mathrm{Ca}^{2+}$ current activated at potentials positive to $-20 \mathrm{mV}$. Moreover, the $\mathrm{Ca}^{2+}$ channels are distributed heterogeneously along the length of the axon, with the higher channel density ( 10-15 channel $\mu \mathrm{m}^{-2}$ ) occurring at the distal one-third of the isolated axons, with respect to the soma. The regions of $\mathrm{Ca}^{2+}$ channel clusters may represent the presynaptic site of the photoreceptor-interneuron synapses. Furthermore, the high-density clusters of $\mathrm{Ca}^{2+}$ channels may augment postsynaptic responses. The results of the present study represent the first direct recordings of $\mathrm{Ca}^{2+}$ currents at presumed synaptic sites. Expression of different $\mathrm{Ca}^{2+}$ channel subtypes at distinct compartments of the type $\mathrm{B}$ photoreceptors may generate diverse $\mathrm{Ca}^{2+}$ domains that may be required for neuronal plasticity in Hermissenda.

Key words: learning; memory; calcium currents; presynaptic calcium channels; photoreceptors; neuronal plasticity; Hermissenda
Classical conditioning in the invertebrate mollusk, Hermissenda crassicornis, after repeated exposures to paired light and motion entails cellular changes in the sensory interactions between the vestibular hair cells, the ocular photoreceptors (Crow and Alkon, 1980; Alkon et al., 1985, 1998; Crow, 1985), and interneurons (Hodgson and Crow, 1992). Studies have shown that type B photoreceptors undergo memory-associated changes, which are generated through enhanced membrane excitability linked to increased input resistance (Alkon et al., 1982; Tomsic and Alkon, 2000) and a reduction in several $\mathrm{K}^{+}$conductances (Alkon et al., 1985). The enhanced synaptic facilitation after conditioning (Schuman and Clark, 1994; Frysztak and Crow, 1997), the differential membrane properties (Yamoah and Crow, 1996; Yamoah et al., 1998) between type B and type A photoreceptors, as well as the synaptic organization of identified photoreceptors and other visual pathway neurons have also been investigated (Crow and Tian, 2000, 2002). However, the aforementioned learninginduced changes have all been analyzed at the soma membrane, whereas little or no information has been reported at the axonal site where the synaptic connections between hair cells, interneurons, and photoreceptors occur.

A fundamental characteristic of learning and memory involves not only changes in the membrane properties but increased efficacy of neurons at the synaptic level, such as in long-term potentiation (LTP) (Lynch et al., 1990; Staubli and Rogers, 1994; Malenka and Nicoll, 1999). Moreover, the enhanced synaptic

Received Aug. 29, 2002; revised Oct. 2, 2002; accepted Oct. 9, 2002.

This work was supported by National Science Foundation Grant IBN0196080 (E.N.Y.).

Correspondence should be addressed to Ebenezer N. Yamoah, Center for Neuroscience, Department of Otolaryngology, University of California, Davis, 1544 Newton Court, Davis, CA 95616. E-mail: enyamoah@ucdavis.edu.

Copyright (C) 2002 Society for Neuroscience 0270-6474/02/2210533-06\$15.00/0 strength as initiated by $\mathrm{Ca}^{2+}$ influx (Lynch et al., 1990) and the consequent rise in intracellular $\mathrm{Ca}^{2+}$ of presynaptic cells seem to be the crucial key to LTP (Linden and Ahn, 1999; Malenka and Nicoll, 1999).

The cellular modifications observed in conditioned Hermissenda have only been observed at the soma of photoreceptors, but changes at the synaptic sites between hair cells, interneurons, and photoreceptors still remain uncertain. Because $\mathrm{Ca}^{2+}$ influx is critical for neurotransmitter release at the synapses, and $\mathrm{Ca}^{2+}$ initiates several short- and long-term changes in neurons, we determined what unique properties axonal $\mathrm{Ca}^{2+}$ channels of the photoreceptors would contribute to the steps in the mechanisms of plasticity in Hermissenda.

\section{MATERIALS AND METHODS}

Isolation of soma and axons of type B photoreceptors. H. crassicornis were purchased from Sea Life Supply (Sand City, CA). Animals were held in modified $50 \mathrm{ml}$ tubes, housed in an artificial seawater (ASW) tank, and maintained at $12-14^{\circ} \mathrm{C}$. Hermissenda were fed scallops and kept on a 12 $\mathrm{hr}$ light/dark cycle. Details of the procedure for isolation of the eyes and photoreceptors of Hermissenda have been described previously by Yamoah and Crow (1994). The CNS was dissected in ASW and allowed to stand for $10 \mathrm{~min}$ at $4^{\circ} \mathrm{C}$. These were then treated with an enzyme mixture consisting of protease XXIV (1 mg/ml) (Sigma, St. Louis, MO) and dispase II (5 mg/ml ASW) (Boehringer Mannheim, Mannheim, Germany) in ASW. The CNS was digested for $15-20 \mathrm{~min}$ at $4^{\circ} \mathrm{C}$ and for another 10-20 $\mathrm{min}$ at room temperature. The preparation was washed using ASW at $4^{\circ} \mathrm{C}$. The eyes were removed surgically, desheathed, transferred into a recording chamber ( $35 \mathrm{~mm}$ sterile culture dish), and observed with an Olympus inverted microscope (IX70; Olympus Optical, Tokyo, Japan). Photoreceptors were identified as type A or B on the basis of their position relative to the lens and optic nerve (see Fig. $1 A, B$ ) (Yamoah and Crow, 1996). Isolated eyes without a lens and the stump of the optic nerve were therefore discarded. For experiments that required the type B photoreceptor axons, only preparations with an axon length of $\geq 90 \mu \mathrm{m}$ were considered acceptable. Using the soma as the reference, 
isolated axons were divided arbitrarily into three equal parts: proximal one-third, middle third, and distal one-third. The average yield for axon isolation procedure was one photoreceptor per animal.

Chemicals and solutions. All chemicals were obtained from Sigma, unless indicated otherwise. ASW was composed of the following (in mM): $390 \mathrm{NaCl}, 10 \mathrm{KCl}, 10 \mathrm{CaCl}_{2}, 23 \mathrm{MgCl}_{2}, 25 \mathrm{MgSO}_{4}, 15 \mathrm{HEPES}$, and $10 \mathrm{D}$-glucose. The solution was sterile filtered, and the $\mathrm{pH}$ was adjusted to 7.8 with $1 \mathrm{M} \mathrm{NaOH}$. Whole-cell $\mathrm{Ca}^{2+}$ currents were recorded using external solution consisting of (in $\mathrm{mM}$ ): 300 choline chloride, $50 \mathrm{MgCl}_{2}$, $20 \mathrm{CaCl}_{2}, 10$ glucose, 5 4-aminopyridine (4-AP), 100 tetraethylammonium acetate (TEA-acetate), and 15 HEPES, sterile filtered and adjusted to a $\mathrm{pH}$ of 7.7 with $1 \mathrm{M}$ TEA-OH. The pipette or internal solution was made up of the following (in mM): $300 \mathrm{CsCl}, 300 \mathrm{~N}$-methyl-D-glucamine, 10 glutathione (reduced), 5 EGTA, 20 TEA-Cl, $5 \mathrm{Mg}(\mathrm{ATP}), 1$ $\mathrm{Na}_{2}$ (GTP), and 40-50 HEPES, pH 7.4, with TEA-OH. Stock solution of $100 \mathrm{~mm}$ BayK 8644 (Calbiochem, La Jolla, CA) was made with DMSO and stored at $-20^{\circ} \mathrm{C}$. Aliquots of the stock solution were added to bath solutions to obtain the desired concentration $(10 \mu \mathrm{M})$. For single-channel recordings, the bath solution contained (in mM): $350 \mathrm{~K}$-glutamate, 100 TEA-Cl, $50 \mathrm{MgCl}_{2}, 10$ D-glucose, $10 \mathrm{CaCl}_{2}, 5$ 4-AP, and $10 \mathrm{HEPES}$, and was adjusted to a $\mathrm{pH}$ of 7.4 with TEA-OH to shift the resting potential to $\sim 0 \mathrm{mV}$. Patch electrodes were filled with (in $\mathrm{mM}$ ): $250 \mathrm{Ba}^{2+}, 100$ TEA-Cl, 5 4-AP, and $10 \mathrm{HEPES}, \mathrm{pH}$ adjusted to 7.4 with TEA-OH. Osmolarity of all solutions ranged from 0.96 to 1 Osm.

Whole-cell and single-channel $\mathrm{Ca}^{2+} / \mathrm{Ba}^{2+}$ current recordings and analysis. Whole-cell recordings were performed using standard patch-clamp recordings with the Axopatch 200B amplifier (Axon Instruments, Foster City, CA) (Hamill et al., 1981). Patch pipettes [borosilicate glass capillaries; $1.5 \mathrm{~mm}$ outer diameter (OD) and $1 \mathrm{~mm}$ inner diameter (ID)] (World Precision Instruments, Sarasota, FL) were pulled with a horizontal electrode puller (Model P-97; Sutter Instruments, Novato, CA). The tips of the pipette were fire polished using a micro-forge (MF-830; Narishige, Tokyo, Japan) to obtain tip diameters of $\sim 1 \mu \mathrm{m}$. The pipette resistances were $1.2 \pm 0.6 \mathrm{M} \Omega(n=30)$ using the pipette solution described above. A 3\% agar bridge with $1 \mathrm{~m} \mathrm{KCl}$ was used as a reference electrode. For single-channel recordings, the cell-attached configuration was used. Patch pipettes were made from borosilicate glass with $2 \mathrm{~mm}$ $\mathrm{OD}$ and $1 \mathrm{~mm}$ ID. The tips of the electrodes were fire polished, and regions close to the tips $(\sim 10 \mu \mathrm{m})$ were coated with Sylgard (Dow Corning, Midland, MI) to reduce the capacitance of the electrodes. Patch pipettes filled with single-channel recording solution had resistances of $1.1 \pm 0.7 \mathrm{M} \Omega(n=51)$. Single-channel patches with seal resistances of $>5 \mathrm{G} \Omega$ were considered to be acceptable for analysis. Single-channel currents were filtered at $1-2 \mathrm{kHz}$ using a low-pass Bessel filter, sampled at $10-40 \mathrm{kHz}$, and stored in a personal computer. The channels were activated at a frequency of $0.2 \mathrm{~Hz}$. Currents were digitized through an analog-to-digital converter (Digidata 1200; Axon Instruments). Data collection of the whole-cell current was controlled with pClamp software (version 8.0; Axon Instruments). However, single-channel currents were acquired using a custom-written software. Data analysis of recorded whole-cell $\mathrm{Ca}^{2+}$ currents was performed using Clampfit 8.1 (Axon Instruments) and Origin 6.0 (Microcal Software, Northampton, MA).

Analysis of single-channel currents was performed using a customwritten software, which is linked to Origin software (Microcal). Leak and capacitative currents were corrected off-line by fitting smooth templates to null traces and subtracting them from active traces. Open-close transitions were detected using half-height threshold analysis criteria. Idealized records were used to generate amplitude histograms and then fitted to a single Gaussian distribution using a Levenberg-Marquardt algorithm to obtain the mean single-channel amplitude and SD. We used a minimum of five voltage steps and their corresponding single-channel currents to determine the unitary conductance. The single-channel current-voltage relationship was fitted by a linear least-square regression line, and single-channel conductance was obtained from the slope of the regression line. Idealized records were also used to construct ensembleaveraged currents and open probability as well as closed- and open-time histograms. All experiments were performed at room temperature $\left(\sim 21^{\circ} \mathrm{C}\right)$. Where appropriate, pooled data were presented as means \pm SD.

\section{RESULTS}

We have shown previously that at least two $\mathrm{Ca}^{2+}$ current subtypes (sustained and transient current) are expressed in the soma of the type B photoreceptors (Yamoah and Crow, 1994). Shown in Figure $1 C$ are $\mathrm{Ca}^{2+}$ current traces recorded from a type $\mathrm{B}$ photoreceptor, from a holding potential of $-80 \mathrm{mV}$ to a test potential of $10 \mathrm{mV}$. When the same cell was held at $-30 \mathrm{mV}$ and stepped to the same test potential, the transient component was suppressed, and the sustained current became apparent. We have reported that the sustained current is sensitive to the dihydropyridines, but the transient current is not (Yamoah and Crow, 1994). To further identify the channels, single-channel currents were recorded using cell-attached patches from type B photoreceptors. Figure $1 D$ illustrates a family of single-channel $\mathrm{Ba}^{2+}$ currents that were recorded before and after the application of 10 $\mu \mathrm{M}$ BayK 8644. Aside from its sensitivity toward BayK 8644, the current was activated from a holding potential of $-30 \mathrm{mV}$ and remained open at the end of a $\sim 300 \mathrm{msec}$ test pulse. This single-channel current thus represents the sustained component. The increase in long openings after application of the dihydropyridine agonist BayK 8644 is a characteristic feature of L-type $\mathrm{Ca}^{2+}$ channels in vertebrate neurons and cardiac cells (Fox et al., 1987; Rodriguez-Contreras and Yamoah, 2001). Moreover, the concentrations of the drug used in these experiments were slightly higher than that required for vertebrate cells. The higher concentrations may be necessary for the high ionic strength of the seawater solutions used for the recordings (Yamoah et al., 1994).

To record the single-channel currents of the transient component, nitrendipine $(20 \mu \mathrm{M})$ was included in the patch pipettes to block the sustained current. Similar methods have been used to isolate single L-type channels in vertebrate hair cells (RodriguezContreras and Yamoah, 2001). The ensuing single-channel current had frequent openings at the first $100 \mathrm{msec}$ of the test potentials and was apparent when patches were held at a more negative holding potential (less than $-70 \mathrm{mV}$ ) (Fig. 1E). Shown in Figure $1 F$ are the single-channel current-voltage relationships of the two subtypes of $\mathrm{Ba}^{2+}$ currents in the $\mathrm{B}$ photoreceptors. The slope conductances of the regression lines for the BayK 8644-sensitive and -insensitive currents were 10 and $17 \mathrm{pS}$, respectively. Patch pipettes containing either $500 \mu \mathrm{M} \mathrm{Cd}^{2+}$ or $5 \mathrm{mM}$ $\mathrm{Co}^{2+}$ yielded no inward $\mathrm{Ba}^{2+}$ current (data not shown). Although the sustained current in the soma of the Hermissenda photoreceptors contained several features that are consistent with L-type $\mathrm{Ca}^{2+}$ channels in neurons (Tsien et al., 1988), the singlechannel conductance is quite distinct. Typically, the singlechannel conductance of L-type $\mathrm{Ba}^{2+}$ currents using 70-110 mM as the charge carrier is $\sim 20-30$ pS (Fox et al., 1987; Elmslie, 1997; Rodriguez-Contreras and Yamoah, 2001). Single-channel data of L-type channels from rat cerebellar neurons reveal distinct gating patterns at different states, one of which has a different conductance (Forti and Pietrobon, 1993). Thus, the distinct conductance of the BayK 8644-sensitive channels in the photoreceptors may reflect subtle differences between L-type channels, suggestive of different channel subtypes in the L-channel class.

In contrast to the soma, the axons of type B photoreceptors expressed only the sustained current with dihydropyridine sensitivity and activation voltage that is more positive than the $17 \mathrm{pS}$ current (Fig. 2A). The single-channel conductance of the axonal $\mathrm{Ba}^{2+}$ currents was $\sim 9 \mathrm{pS}$ (Fig. $2 B$ ). Because similar methods were used to isolate the soma and axons, it is unlikely that the enzyme dissociation procedure used contributed toward the observed differences in channel expression. We determined the kinetics of the axonal $\mathrm{Ba}^{2+}$ currents from patches containing single channels to assess their open and shut (closed) times. Figure $3 A$ shows the dwell and shut time histograms of the channel at a test potential of $10 \mathrm{mV}$. The open and shut time 
A

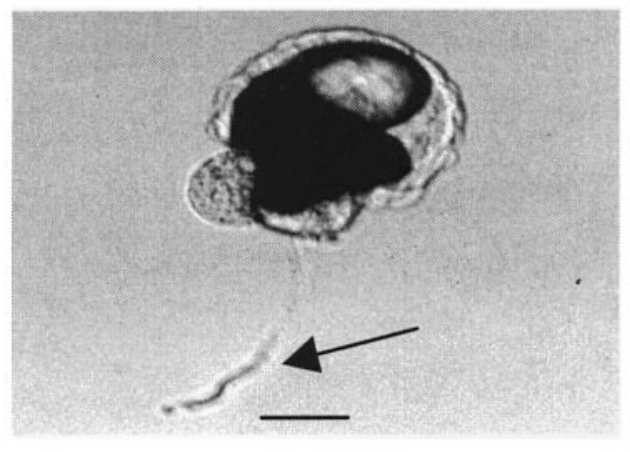

B

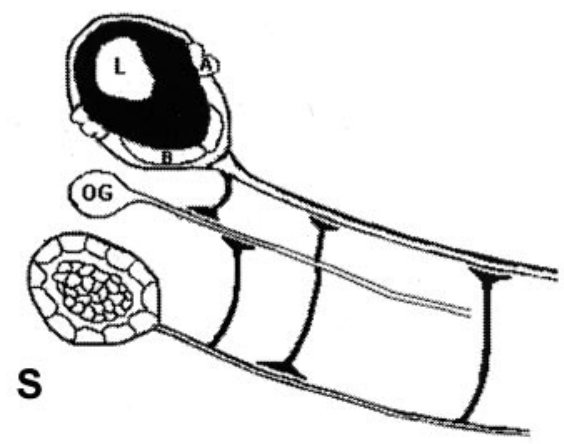

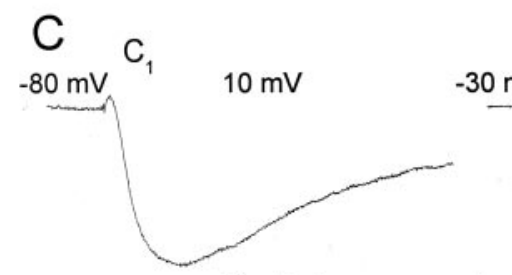
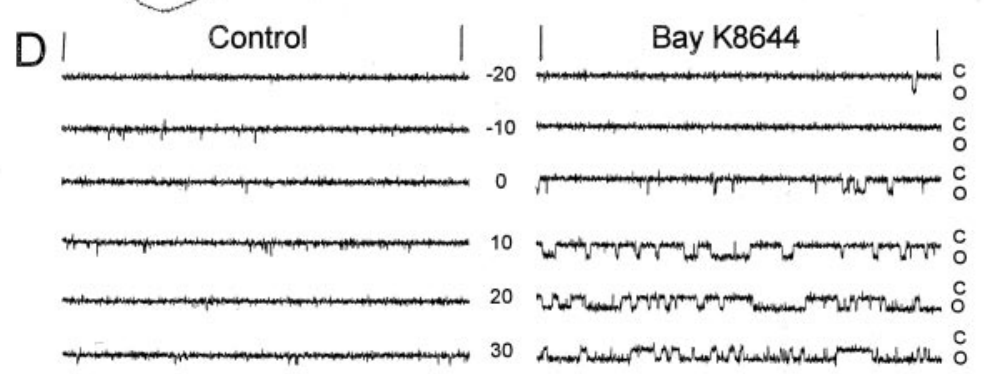

$10 \mathrm{mV}$

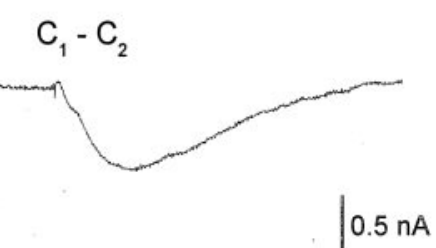

$E$

$100 \mathrm{~ms}$
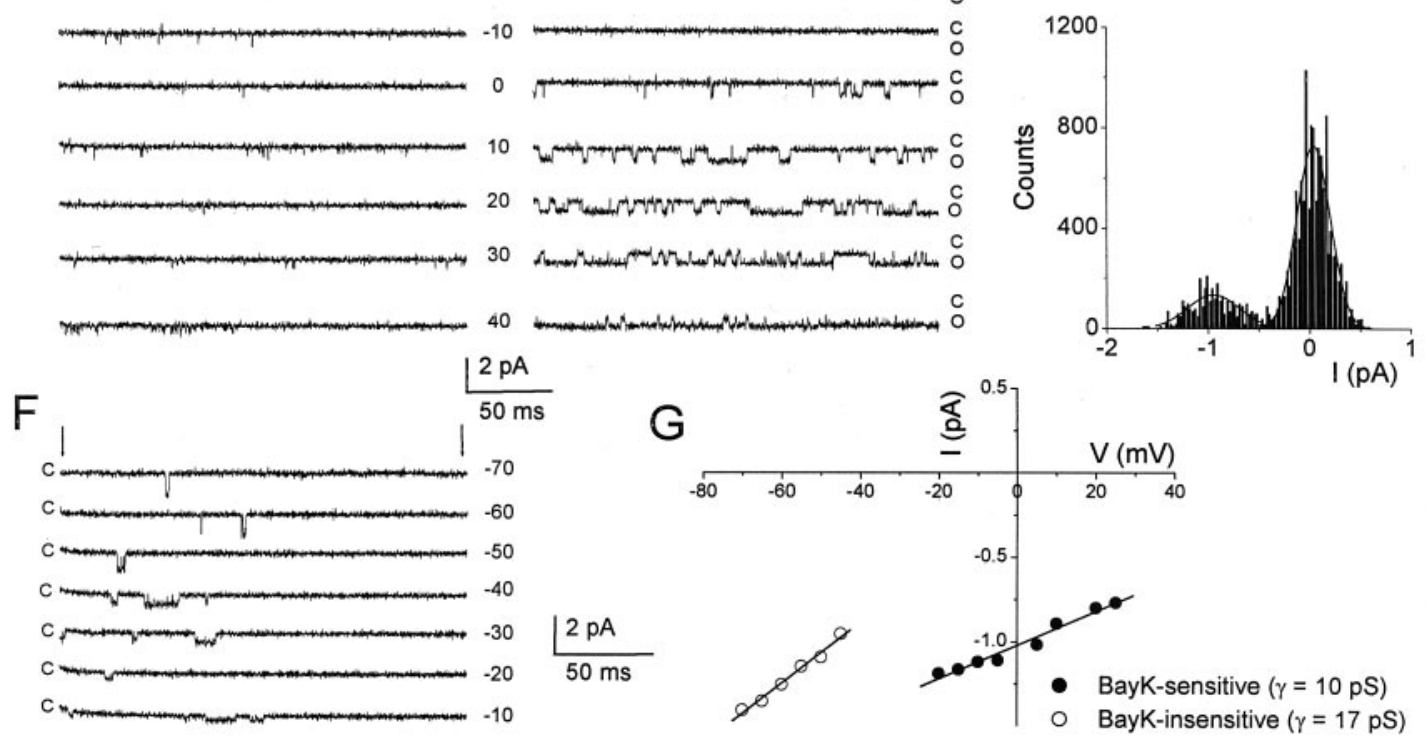

Figure 1. $\mathrm{Ca}^{2+}$ currents in soma of type B photoreceptors. A, Photomicrograph of isolated Hermissenda eye preparation with an intact axon. The arrow shows an axon $\sim 120 \mu \mathrm{m}$ in length. $B$, Schematic diagram of the eye and the statocyst $(S)$ with associated synaptic connections along the axons of the photoreceptors. Scale bar, $40 \mu \mathrm{m}$. $L$, Lens; $A, B$, type B and A photoreceptors; $O G$, optic ganglion. $C$, Whole-cell Ca ${ }^{2+}$ currents recorded by eliminating inward $\mathrm{Na}^{+}$currents and suppressing outward $\mathrm{K}^{+}$currents with choline substitution of external $\mathrm{Na}^{+}$and using bath TEA and 4-AP, respectively. The current trace recorded from a holding potential of $-80 \mathrm{mV}$ and a step potential of $10 \mathrm{mV}\left(C_{7}\right)$ consists of a transient and sustained component. The transient component was suppressed when the cell was held at $-30 \mathrm{mV}\left(C_{2}\right)$. The difference current $\left(C_{1}-C_{2}\right)$ revealed the transient current. $D$, A family of seven consecutive sweeps of single-channel current traces recorded in the cell-attached configuration showing brief single-channel opening events. The charge carrier for the single-channel recordings was $250 \mathrm{mM} \mathrm{Ba}^{2+}$. Bath application of $10 \mu \mathrm{M}$ BayK 8644 resulted in long-duration openings. The holding potential of the patch was $-30 \mathrm{mV}$, and the step potentials are indicated. The closed and open levels are denoted as $C$ and $O$, respectively. $E$, Typical amplitude histogram used to determine the unitary amplitude of single-channel currents. The example shown was generated from current traces elicited at a step potential of $20 \mathrm{mV} . F$, In contrast to the BayK 8644-sensitive current, another single-channel current was recorded from the B-cell somata that showed openings at the first $100 \mathrm{msec}$ of the test pulse. The patch pipette contained $20 \mu \mathrm{M}$ nitrendipine. The current became apparent when patches were held at more negative potentials; the holding potential of the current traces shown is $-90 \mathrm{mV}$, and the step potentials are indicated beside the traces. The low voltage-activated current was insensitive to BayK 8644 (data not shown). $G$, The corresponding current-voltage relationships for the BayK 8644-sensitive $(\bullet)$ and -insensitive $(\bigcirc)$ currents are shown, and the conductances $(\gamma)$ were 10 and $17 \mathrm{pS}$, respectively. Analysis of seven patches of BayK 8644 -sensitive and -insensitive currents produced a mean conductance $(9.7 \pm 1.4 \mathrm{pS}$ and $16.6 \pm 3.1 \mathrm{pS})$, respectively. 


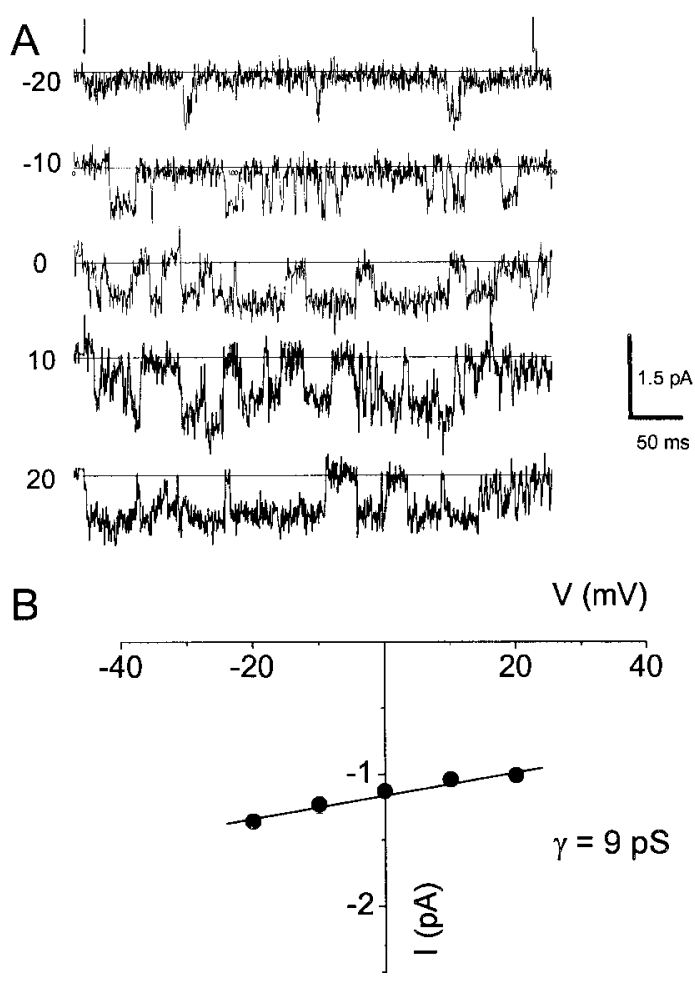

Figure 2. Single-channel $\mathrm{Ba}^{2+}$ currents from type $\mathrm{B}$ photoreceptor axons. $A$, Representative unitary $\mathrm{Ba}^{2+}$ current traces recorded from the photoreceptor axon in the presence of $10 \mu \mathrm{M}$ BayK 8644 and elicited from a holding potential of $-70 \mathrm{mV}$ using test potentials as indicated (vertical lines indicate the beginning of the test pulses). Horizontal lines represent zero current levels. $B$, The corresponding current-voltage relationship was plotted as mean \pm SD. The calculated single-channel conductance $(\gamma)$ is $9 \mathrm{pS}$. Summary data from nine similar patches yielded a mean conductance of $8.9 \pm 1.5 \mathrm{pS}$.

distributions were best fitted by the sum of two exponential functions, with time constants of open and shut distributions as follows: $\tau_{\text {dwell, } 1}=0.09 \mathrm{msec}$ and $\tau_{\text {dwell, } 2}=1.6 \mathrm{msec} ; \tau_{\text {shut }, 1}=0.17$ msec and $\tau_{\text {shut }, 2}=3.4 \mathrm{msec}$, respectively (Fig. $3 A, B$ ).

\section{DISCUSSION}

Indirect evidence for the differential distribution of $\mathrm{Ca}^{2+}$ channels in the somata and axons of neurons has been inferred from action potential-evoked responses from crayfish, lamprey, rat hippocampal, and cerebellar cultured neurons (Delaney et al., 1991; Backsai et al., 1995; Mackenzie et al., 1996; Forti et al., 2000). Moreover, reports using antibodies raised against the $\mathrm{Ca}^{2+}$ channel subtypes $\mathrm{Ca}_{\mathrm{v}} 2.1, \mathrm{Ca}_{\mathrm{v}} 2.2$, and $\mathrm{Ca}_{\mathrm{v}} 2.3$ have revealed immunohistochemical evidence for the heterogeneous distribution of these $\mathrm{Ca}^{2+}$ channels in the axon, dendrites, and soma of neurons (Volsen et al., 1995; Westenbroek et al., 1995). Aside from the important role of voltage-gated $\mathrm{Ca}^{2+}$ channels (VGCCs) in mediating $\mathrm{Ca}^{2+}$ influx, which is necessary for normal neuronal functions (e.g., triggering of neurotransmitter release), the axonal $\mathrm{Ca}^{2+}$ currents may regulate the firing rate of propagated action potentials through activation of $\mathrm{Ca}^{2+}$-dependent $\mathrm{K}^{+}$channels (Callewaert et al., 1996). Furthermore, $\mathrm{Ca}^{2+}$ storage organelles have been located in axons, raising the possibility that biological phenomena such as $\mathrm{Ca}^{2+}$-induced $\mathrm{Ca}^{2+}$ release may occur during the conduction of action potentials and neurotransmitter release (Ogden et al., 1993; Forti et al., 2000). For the type B

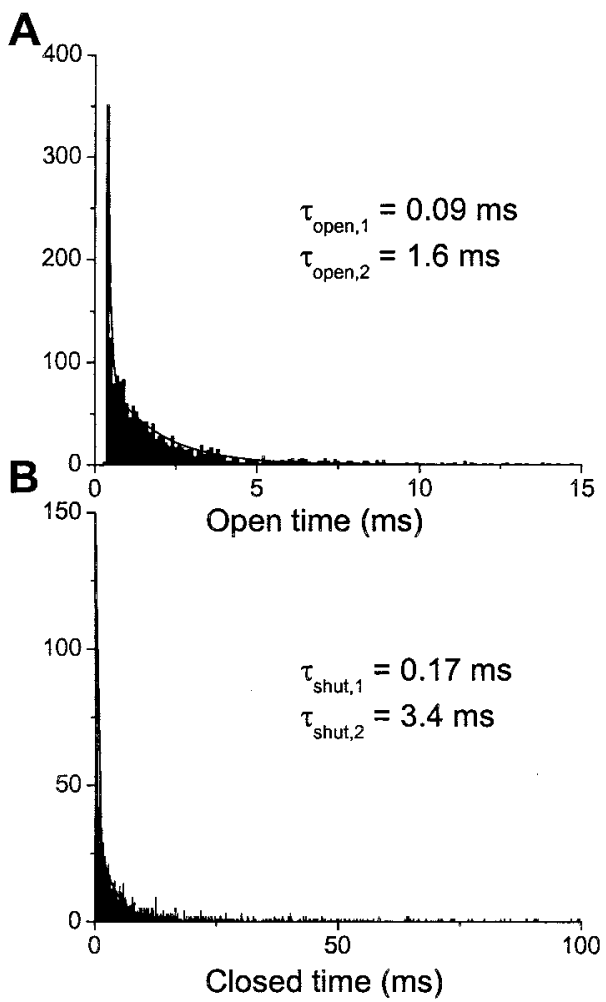

Figure 3. Kinetics of single-channel $\mathrm{Ba}^{2+}$ currents in type $\mathrm{B}$ photoreceptor axons. $A$, An open-time histogram of axonal single $\mathrm{Ba}^{2+}$ currents was generated from traces elicited at a test potential of $10 \mathrm{mV}$. The histogram was fitted using two exponential functions. The time constants $(\tau)$ of the open time for the example shown are indicated. $B$, The shut (closed-time) distribution histogram was also fitted with two $\tau$ values as shown. Analyses of the open- and closed-time distribution were performed on axonal patches that contained single channels. Mean data from five patches for the open and shut times of traces elicited at a test potential of $10 \mathrm{mV}$ were as follows: $\tau_{\text {open }, 1}=0.1 \pm 0.06 \mathrm{msec} ; \tau_{\text {open }, 2}=1.8 \pm 0.5$ $\mathrm{msec} ; \tau_{\text {shut }, 1}=0.15 \pm 0.08 \mathrm{msec} ; \tau_{\text {shut }, 2}=3.2 \pm 1.8 \mathrm{msec}$.

photoreceptors, differential expression of $\mathrm{Ca}^{2+}$ channels may support the compartmentalization of $\mathrm{Ca}^{2+}$-dependent mechanisms, which has been debated as one of the necessary events that may occur during classical conditioning (Crow, 1985; Alkon and Rasmussen, 1988). Typically, $\mathrm{Ca}^{2+}$ channels at presynaptic terminals consist of non L-type channels (Wu et al., 1999). However, for synapses in which there is tonic transmitter release, the L-type channel plays a major role in triggering transmitter release, raising the possibility that axonal $\mathrm{Ca}^{2+}$ channels in $\mathrm{B}$ photoreceptors may mediate tonic release.

The presence of $\mathrm{Ca}^{2+}$ microdomains, moreover, may extend beyond axon-soma compartments. There were remarkable variations in the number of channels in axon-attached and nullchannel patches, using patch electrodes with similar diameters and resistances. We divided $90 \mu \mathrm{m}$ axons into proximal, middle, and distal thirds and determined the channel densities of the patches. A total of 59 patches were examined: 16 patches from the proximal third, 19 from the middle third, and 24 from the distal third. Only one patch from the proximal third contained a channel $(6 \%)$. In addition, the seven patches $(37 \%)$ in the middle third contained channels, and 22 patches $(92 \%)$ in the distal third had single-channel or multichannel events. Shown in Figure $4 A$ are a family of consecutive current traces recorded from a patch from the distal third of a type B photoreceptor axon. Using the bino- 

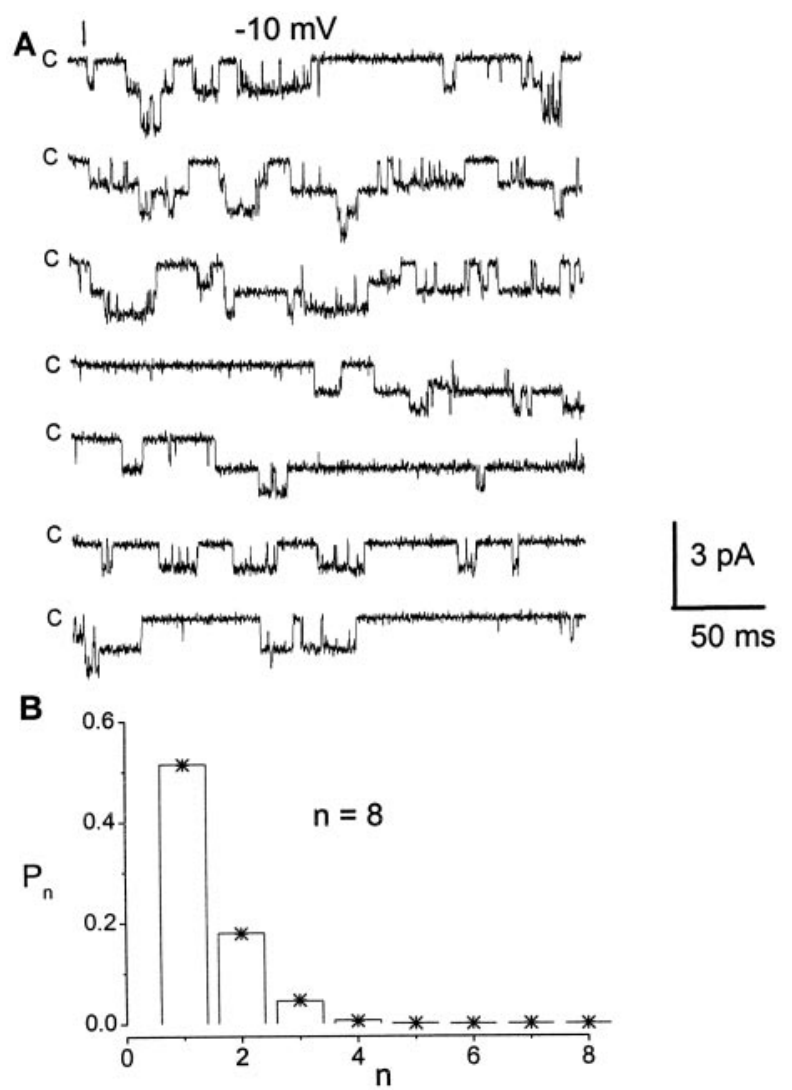

Figure 4. Multiple-channel patches in the distal one-third of a type B photoreceptor axon. $A$, A family of seven consecutive traces recorded from an axon-attached patch at the distal one-third of an $\sim 100 \mu \mathrm{m}$ axon. The patch was held at $-60 \mathrm{mV}$ and stepped to a test potential of $-10 \mathrm{mV}$. The closed levels are indicated as $C$, and the arrow denotes the time when the test pulse was initiated. $B$, Bar graphs showing the probability that a given number of channels was open $\left(P_{n}\right)$ against the number of channels ( $n$ ) obtained from the same patch as $A$. The columns represent the experimental data using the measured values for each unitary current level. Asterisks indicate the probability $\left(P_{\mathrm{n}}\right)$ predicted by the following binomial theorem: $P_{\mathrm{n}}=[N ! / n !(N-n) !] P_{\mathrm{o}}{ }^{\mathrm{n}}\left(1-P_{\mathrm{o}}\right)^{\mathrm{N}-{ }_{\mathrm{n}}}, n=0,1, \ldots N$, where $N$ and $P_{\mathrm{o}}$ represent the number of functional channels and the open probability of individual channels, respectively. The predicted probability that an individual channel is open $\left(P_{\mathrm{o}}\right)=0.102$; the number of functional channels $(N)=8$. The capacitance of the patch was estimated to be $\sim 10$ $\mathrm{pF}$, and assuming a specific membrane capacitance of $10 \mathrm{mF} \mathrm{m}^{-2}$, the channel density was $\sim 13$ channels $\mu \mathrm{m}^{-2}$. The mean channel density of multiple-channel patches recorded from the distal one-third of the B photoreceptors was $12.7 \pm 2.9$ channels $\mu \mathrm{m}^{-2}(n=9)$.

mial distribution, we estimated that there were $\sim 8$ channels in the patch (Fig. 4B). The capacitance of the patch membrane was estimated to be $\sim 10 \mathrm{pF}$ (Rodriguez-Contreras and Yamoah, 2001). Thus, assuming a specific membrane capacitance of $10 \mathrm{mF}$ $\mathrm{m}^{-2}$, the channel density was determined as $N$ per patch capacitance and expressed as the number of channels per square micrometer.

The axons of the type B photoreceptors serve not only as postsynaptic sites for neuritic projections from the presynaptic hair cells (Alkon and Fuortes, 1972) but also represent presynaptic loci for downstream interneurons (Hodgson and Crow, 1992). Although the present experiments do not allow for identification of the exact synaptic site, versa vi, presynaptic and postsynaptic, it would be reasonable to infer that the sites of high $\mathrm{Ca}^{2+}$ channel density correspond to the presynaptic regions. The values obtained for the channel density (10-15 channels $\mathrm{m}^{-2}$ ) resemble the $\mathrm{Ca}^{2+}$ channel density in presynaptic terminals of the chick ciliary ganglion and bullfrog saccular hair cells (Haydon et al., 1994; Rodriguez-Contreras and Yamoah, 2001). However, it is equally possible that some of the $\mathrm{Ca}^{2+}$ channel clusters and solitary channels may be poised at postsynaptic sites to augment $\mathrm{Ca}^{2+}$ influx after neurotransmitter-mediated depolarization.

Axons and dendrites may be involved not only in signal transmission but also in signal transduction. Several forms of neuronal plasticity may be mediated through $\mathrm{Ca}^{2+}$ entry into mammalian axons via VGCCs (Callewaert et al., 1996; Beck et al., 2001; Jackson et al., 2001; Verbny et al., 2002). Although $\mathrm{Ca}^{2+}$ influx and synaptic contacts between Hermissenda hair cells, interneurons, and photoreceptors are crucial to plasticity during conditioning, the exact mechanism remains unknown. Direct measurements of the $\mathrm{Ca}^{2+}$ currents in the photoreceptor axons, as described in this study, are a first step toward our understanding of the contribution of axons in the mechanisms underlying conditioning-associated plasticity in Hermissenda.

\section{REFERENCES}

Alkon DL, Fuortes MG (1972) Responses of photoreceptors in Hermissenda. J Gen Physiol 60:631-649.

Alkon DL, Rasmussen H (1988) A spatial-temporal model of cell activation. Science 239:998-1005.

Alkon DL, Lederhendler I, Shoukimas JJ (1982) Primary changes of membrane currents during retention of associative learning. Science 215:693-695.

Alkon DL, Sakakibara M, Forman R, Harrigan J, Lederhendler I, Farley $\mathrm{J}$ (1985) Reduction of two voltage-dependent $\mathrm{K}^{+}$currents mediates retention of a learned association. Behav Neural Biol 44:278-300.

Alkon DL, Nelson TJ, Zhao W, Cavallaro S (1998) Time domains of neuronal $\mathrm{Ca}^{2+}$ signaling and associative memory: steps through a calexcitin, ryanodine receptor, $\mathrm{K}^{+}$channel cascade. Trends Neurosci 21:529-537.

Backsai BJ, Wallen P, Lev-Ram V, Grillner S, Tsien RY (1995) Activityrelated calcium dynamics in lamprey neurons as revealed by video-rate confocal microscopy. Neuron 14:19-28.

Beck A, Lohr C, Deitmer JW (2001) Calcium transients in subcompartments of the leech Retzius neuron as induced by single action potentials. J Neurobiol 1-18.

Callewaert G, Eilers J, Konnerth A (1996) Axonal calcium entry during fast "sodium" action potentials in rat cerebellar Purkinje neurones. J Physiol (Lond) 495:641-647.

Crow T (1985) Conditioned modification of phototactic behavior in Hermissenda. II. Differential adaptation of B-photoreceptors. J Neurosci $5: 215-223$

Crow T, Alkon DL (1980) Associative behavioral modification in Hermissenda: cellular correlates. Science 209:412-414.

Crow T, Tian LM (2000) Monosynaptic connections between identified $\mathrm{A}$ and $\mathrm{B}$ photoreceptors and interneurons in Hermissenda: evidence for labeled-lines. J Neurophysiol 84:367-375.

Crow T, Tian LM (2002) Morphological characteristics and central projections of two types of interneurons in the visual pathway of Hermissenda. J Neurophysiol 87:322-332.

Delaney K, Tank D, Zuker RS (1991) Presynaptic calcium and serotonin-mediated enhancement of transmitter release at crayfish neuromuscular junction. J Neurosci 11:2631-2643.

Elmslie KS (1997) Identification of the single channels that underlie the N-type and L-type calcium currents in bullfrog sympathetic neurons. J Neurosci 17:2658-2668.

Forti L, Pietrobon D (1993) Functional diversity of L-type calcium channels in rat cerebellar neurons. Neuron 10:437-450.

Forti L, Pouzat C, Llano I (2000) Action potential-evoked $\mathrm{Ca}^{2+}$ signals and calcium channels in axons of developing rat cerebellar interneurons. J Physiol (Lond) 527:33-48.

Fox AP, Nowycky MC, Tsien RW (1987) Kinetic and pharmacological properties distinguishing three types of calcium currents in chick sensory neurons. J Physiol (Lond) 394:149-172.

Frysztak RJ, Crow T (1997) Synaptic enhancement and enhanced excitability in presynaptic and postsynaptic neurons in the conditioned stimulus pathway of Hermissenda. J Neurosci 17:4426-4433.

Hamill OP, Marty A, Neher E, Sakmann B, Sigworth FJ (1981) Improved patch-clamp techniques for high-resolution current recording from cells and cell-free membrane patches. Pflügers Arch 391:85-100.

Haydon PG, Henderson E, Stanley EF (1994) Localization of individual 
calcium channels at the release face of a presynaptic nerve terminal. Neuron 13:1275-1280.

Hodgson TM, Crow T (1992) Cellular correlates of classical conditioning in identified light responsive pedal neurons of Hermissenda crassicornis. Brain Res 570:267-271.

Jackson VM, Trout SJ, Brain KL, Cunnane TC (2001) Characterization of action potential-evoked calcium transients in mouse postganglionic sympathetic axon bundles. J Physiol (Lond) 537:3-16.

Linden DJ, Ahn S (1999) Activation of presynaptic cAMP-dependent protein kinase is required for induction of cerebellar long-term facilitation. J Neurosci 19:10221-10227.

Lynch G, Kessler M, Arai A, Larson J (1990) The nature and causes of hippocampal long-term facilitation. Prog Brain Res 436:177-183.

Mackenzie PJ, Umemiya M, Murphy TH (1996) $\mathrm{Ca}^{2+}$ imaging of CNS axons in culture indicates reliable coupling between single action potentials and distal functional release sites. Neuron 16:783-795.

Malenka RC, Nicoll RA (1999) Long-term potentiation-a decade of progress? Science 285:1870-1874.

Ogden DC, Khodakhah K, Carter TD, Gray PT, Capiod T (1993) Mechanisms of intracellular calcium release during hormone and neurotransmitter action investigated with flash photolysis. J Exp Biol 184:105-127.

Rodriguez-Contreras A, Yamoah EN (2001) Direct measurement of single-channel $\mathrm{Ca}^{2+}$ currents in bullfrog hair cells reveals two distinct channel subtypes. J Physiol (Lond) 534:669-689.

Schuman EM, Clark GA (1994) Synaptic facilitation at connections of Hermissenda type B photoreceptors. J Neurosci 14:1613-1622.

Staubli U, Rogers G (1994) Facilitation of glutamate receptors enhances memory. Proc Natl Acad Sci USA 91:777-781.

Tomsic D, Alkon DL (2000) Background illumination effects upon in vitro conditioning in Hermissenda. Neurobiol Learn Mem 74:56-64.
Tsien RW, Lipscombe D, Madison DV, Bley KR, Fox AR (1988) Multiple types of neuronal calcium channels and their selective modulation. Trends Neurosci 11:431-438.

Verbny Y, Zhang C-L, Chiu SY (2002) Coupling of calcium homeostasis to axonal sodium in axons of mouse optic nerve. J Neurophysiol 88:802-816.

Volsen SG, Day NC, McCormack AL, Smith W, Craig PJ, Beattie R, Ince PG, Shaw PJ, Ellis SB, Gillespie A, Harpold MM, Lodge D (1995) The expression of neuronal voltage-dependent calcium channels in human cerebellum. Brain Res Mol Brain Res 34:271-282.

Westenbroek RE, Sakurai T, Elliott EM, Hell JW, Starr TV, Snutch TP, Catterall WA (1995) Immunochemical identification and subcellular distribution of the $\alpha 1 \mathrm{~A}$ subunits of brain calcium channels. J Neurosci 15:6403-6418.

Wu L-G, Westenbroek RE, Borst JGG, Catterall WA, Sakmann B (1999) Calcium channel types with distinct presynaptic localization couple differentially to transmitter release in single calyx-type synapses. J Neurosci 19:726-736.

Yamoah EN, Crow T (1994) Two components of calcium currents in the soma of photoreceptors of Hermissenda. J Neurophysiol 72:1327-1336.

Yamoah EN, Crow T (1996) Protein kinase and G-protein regulation of $\mathrm{Ca}^{2+}$ currents in Hermissenda photoreceptors by 5-HT and GABA. J Neurosci 16:4799-4809.

Yamoah EN, Kuzirian AM, Sanchez-Andres JV (1994) Calcium current and inactivation in identified neurons in Hermissenda. J Neurophysiol 72:2198-2207.

Yamoah EN, Matzel L, Crow T (1998) Expression of different types of inward rectifier currents confers specificity of light and dark responses in type A and B photoreceptors of Hermissenda. J Neurosci 18:65016511 . 